\title{
Complete resections of giant thorax masses and experienced difficulties
}

\author{
Bülent Mustafa \\ YENIGÜN ${ }^{1}$ (ID) \\ Cabir YÜKSEL ${ }^{1}(I D)$ \\ Farruh IBRAHIMOV ${ }^{1}$ (ID) \\ Uğurum YÜCEMEN ${ }^{\mathbf{1}}$ (ID) \\ Ayşegül GÜRSOY \\ ÇORUH $^{2}$ (ID) \\ Yusuf KAHYA ${ }^{1}(I D)$ \\ Gökhan KOCAMAN ${ }^{\mathbf{1}}$ (ID) \\ Murat ÖZKAN ${ }^{1}$ (ID) \\ Serkan ENÖN ${ }^{1}$ (ID) \\ Ayten KAYI CANGIR ${ }^{\mathbf{1}}$ (ID)
}

Cite this article as: Yenigün $B M$, Yüksel $C$, ibrahimov $F_{\text {, }}$ Yücemen U, Gürsoy Çoruh A, Kahya Y, et al. Complete resections of giant thorax masses and experienced difficulties. Tuberk Toraks 2020;68(3):278-284.

\section{Yazışma Adresi (Address for Correspondence)}

Dr. Bülent Mustafa YENIGÜN

Ankara Üniversitesi Tıp Fakültesi,

Göğüs Cerrahisi Anabilim Dalı,

ANKARA - TÜRKIYE

e-mail: drbulent18@hotmail.com

CCopyright 2020 by Tuberculosis and Thorax.

Available on-line at www.tuberktoraks.org.com
${ }^{1}$ Department of Thoracic Surgery, Faculty of Medicine, Ankara University, Ankara, Turkey

1 Ankara Üniversitesi Tıp Fakültesi, Gögüs Cerrahisi Anabilim Dalı, Ankara, Türkiye

2 Department of Radiology, Faculty of Medicine, Ankara University, Ankara, Turkey

${ }^{2}$ Ankara Üniversitesi Tıp Fakültesi, Radyoloji Anabilim Dalı, Ankara, Türkiye

\begin{abstract}
Complete resections of giant thorax masses and experienced difficulties

Introduction: Thoracic giant masses do not have a clear definition. In some publications, giant thoracic mass definition is used in tumors whose long axis is $>10 \mathrm{~cm}$ and in other publications covering more than $50 \%$ of the hemithorax. In this study, demographic data of patients with a massive resectable giant thoracic mass and the difficulties and experiences experienced in the peroperative process were reviewed with a general perspective.
\end{abstract}

Materials and Methods: 14 giant intrathoracic masses operated at the department of Thoracic Surgery, School of Medicine, Ankara University were included in the study. The masses occupying more than half of the hemithorax and mediastinal lesions with a long axis of $15 \mathrm{~cm}$ or larger radiologically were included and evaluated.

Results: 9 (64.3\%) of our patients were male and 9 (35.7\%) were female. The average age was $49.2 \pm 17.1$ (between 18-68). The tumor localizations of our patients were determined as $9(64.2 \%)$ hemithorax and $5(35.8 \%)$ mediastinal. When the radiological and intraoperative dimensions were examined separately, it was observed that the mean of long axis of CT image is average $18 \pm 3.8 \mathrm{~cm}$ (between $12 \mathrm{~cm}$ and $26 \mathrm{~cm}$ ), and the mean of long axis of specimen is average $18.14 \pm 3.6 \mathrm{~cm}$ (between $15 \mathrm{~cm}$ and $23 \mathrm{~cm}$ ). The heaviest mass was average $844 \pm 473 \mathrm{~g}$ (350 g-2204 g).

Conclusion: The surgical maneuvers and hence the excision of giant masses become difficult to operate due to the narrow localization of the masses and the frequent invasions of adjacent vascular structures and nerve tissues. However, complete resection of these slowly growing and generally encapsulated masses can provide the cure.

Key words: Thoracic surgery; malignancy; giant mass 


\section{Öz}

\section{Dev toraks kitlelerinin komplet rezeksiyonları ve yaşanan güçlükler}

Giriş: Torasik dev kitlelerin net bir tanımı yoktur. Bazı yayınlarda uzun aksının $>10 \mathrm{~cm}$ 'den fazla olan, bazı yayınlarda ise hemitoraksın \%50'sinden fazlasını kaplayan tümörlerde dev torasik kitle tanımlaması kullanılmaktadır. Bu çalışmada komplet rezeke edilebilen dev torasik kitlesi olan hastaların demografik verileri ve peroperatif süreçte yaşanan güçlükler, deneyimler genel perspektif ile gözden geçirilmiştir.

Materyal ve Metod: Ankara Üniversitesi Tıp Fakültesi Göğüs Cerrahisi Anabilim Dalında Ocak 2015 ve Ocak 2020 tarihleri arasında opere edilen hemitoraksın \%50'sinde fazla yer kaplayan ya da mediasten yerleşimli uzun çapı 15 cm'den büyük 14 torasik dev kitle çalışmaya alındı.

Bulgular: Hastalarımızın 9'u (\%64.3) erkek, 5'i (\%35.7) kadındı. Yaş ortalaması $49.2 \pm 17.1$ idi. Tümör lokalizasyonları 9'u (\%64.2) hemitoraks, 5'i (\%35.8) mediastinal yerleşimliydi. Radyolojik ve intraoperatif boyutlar ayrı ayrı bakıldığında radyolojik uzun aks ort. $18 \pm 3.8 \mathrm{~cm}(12 \mathrm{~cm}-26 \mathrm{~cm})$, piyes uzun aks ort. $18.14 \pm 3.6 \mathrm{~cm}$ idi $(15 \mathrm{~cm}-23 \mathrm{~cm})$. En ağır kitle $844 \pm 473 \mathrm{~g}$. idi $(350 \mathrm{~g}-2204 \mathrm{~g})$.

Sonuç: Dev kitlelerin eksizyonu, kitlelerin bulunduğu alanların kısıtı olması, cerrahi manevraların güçlüğü, komşu vasküler yapılar ile sinir dokularına invazyonların sık görülmesine bağlı olarak çok zordur. Ancak yavaş büyüyen ve genelde kapsüllü olan bu kitlelerin komplet rezeksiyonu kür sağlayabilir.

Anahtar kelimeler: Göğüs cerrahisi; malignite; dev kitle

\section{INTRODUCTION}

Though the exact definition of thoracic giant masses is unclear, they can be named as masses covering more than $50 \%$ of the hemithorax in a few publications or with a long axis more than 10-15 cm. It is close to the tissues of vital importance as a place of residence and the possibility of invasion to these tissues is high. Surgical resection is also very important. Intrathoracic giant masses are lesions that can cause symptoms to occur late due to their slow growth and are eventually difficult to resect. They are usually asymptomatic and may be symptomatic when the findings regarding compression and invasion occur as a result of overgrowth of the lesions. Due to the presence of mediastinal masses that are largely localized in major vascular and neural tissues, invasion of tumors into surrounding tissues is frequently observed, thus resection becomes rather difficult (1-3). Besides, since these masses are rich in vascularization, and there is limited mobilization, hence narrow operational area in the surgical procedure, it may cause surgical maneuvers to become too difficult, and complete resection may be problematic (4). In our study, we investigated the giant thoracic masses that could be resected completely and aim to propose the initial series that could guide the surgical pathologies, going beyond the limited case reports so far.

\section{MATERIALS and METHODS}

Among 1112 patients whom major surgical operation performed between January 2014 and June 2019 at the Department of Thoracic Surgery in Faculty of
Medicine, Ankara University, the study included 14 $(1.2 \%)$ patients. All patients were screened through preoperative PA chest radiography, thorax computed tomography $(\mathrm{CT})$, magnetic resonance imaging (MRI) (if the mass is suspected of invasion into the surrounding soft tissues) and positron emission tomography (PET-CT). Thanks to these assessment, the relationship of the mass with the surrounding tissues and the degree of invasion were determined. The presence of cardiac invasion was investigated with transthoracic echocardiogram (TTE) and Cine MRI. There were patients who underwent transthoracic needle aspiration due to pathologies that would require medical treatment in differential diagnosis. Surgery approach, neo/adjuvant and/or radiotherapy treatment decisions were taken by the multidisciplinary tumor council.

\section{RESULTS}

A total of 14 patients [9 (\%64) male and 5 (\%36) female] $9(64 \%)$ were included in the study. The mean of age is $49.2 \pm 17.1$ (between 18-68). The symptoms of the patients included chest pain, weight loss, dyspnea, and hemoptysis. The tumor localizations of our patients were determined as $9(64.2 \%)$ hemithorax and 5 (35.8\%) mediastinal. Transthoracic biopsy was performed to 8 patients (57\%). Thoracotomy was performed with $9(64.2 \%)$ patients, and median sternotomy was performed with 5 $(35.2 \%)$ patients (Figure 1) (Table 1) When the radiological and intraoperative dimensions are examined separately, it is observed that the mean of the long axis of CT image is $18 \pm 3.8 \mathrm{~cm}$ (between $12 \mathrm{~cm}$ and 
Table 1. General characteristics of patient

\begin{tabular}{|c|c|c|c|c|c|}
\hline Number & Gender & $\begin{array}{c}\text { Age old-year } \\
49.2 \pm 17.1(18-68)\end{array}$ & Localization & $\begin{array}{c}\text { PET CT (SUVmax) } \\
6.6 \pm 4.6(1.9-16.9)\end{array}$ & $\begin{array}{l}\text { CT Dimension }(\mathrm{cm}) \\
18 \pm 3.8 \mathrm{~cm}(12-26)\end{array}$ \\
\hline 1 & $\mathrm{~m}$ & 28 & M & 4.6 & 26 \\
\hline 2 & $\mathrm{~m}$ & 56 & HT & 5.9 & 18 \\
\hline 3 & $\mathrm{~m}$ & 32 & M & 3.5 & 12 \\
\hline 4 & $\mathrm{~m}$ & 22 & $\mathrm{HT}$ & 15 & 17 \\
\hline 5 & $\mathrm{~m}$ & 45 & M & 1.9 & 17 \\
\hline 6 & $f$ & 58 & $\mathrm{HT}$ & 8.67 & 18 \\
\hline 7 & $f$ & 63 & HT & 16.9 & 12 \\
\hline 8 & $\mathrm{~m}$ & 66 & $\mathrm{HT}$ & 2.2 & 17 \\
\hline 9 & $\mathrm{~m}$ & 68 & $\mathrm{HT}$ & 3.8 & 12.5 \\
\hline 10 & $\mathrm{~m}$ & 59 & HT & 7.44 & 17 \\
\hline 11 & $\mathrm{~m}$ & 59 & $\mathrm{HT}$ & 2.9 & 15 \\
\hline 12 & $f$ & 64 & $\mathrm{HT}$ & 7.8 & 12 \\
\hline 13 & $f$ & 18 & M & - & 16 \\
\hline 14 & $f$ & 51 & M & 5.7 & 16 \\
\hline
\end{tabular}

$26 \mathrm{~cm}$ ), and the mean of the long axis of specimen is $18.14 \pm 3.6 \mathrm{~cm}$ (between $15 \mathrm{~cm}$ and $23 \mathrm{~cm}$ ). The heaviest mass was average $844 \pm 473$. (between 3502204). The mean of PET/CT evaluation of the patients is SUVmax value is $6.6 \pm 4.6$ (between 1.9-16.9) (Table 1). Pathologic diagnoses were determined to be $3(21 \%)$ solitary fibrous tumor (SFT), 2 (15\%) leiomyosarcoma, 2 (15\%) germ cell tumor, 1 (7\%) schwannoma, 1 (7\%) thymolipoma, 1 (7\%) desmoid tumor, $1(7 \%)$ spindle cell carcinoma (Figure 1), 1 (7\%) gastrointestinal stromal tumor (GIST), 1 (7\%) thymoma (WHO classification type $\mathrm{AB}$ thymoma) and $1(7 \%)$ castleman disease (Table 2). A wound infection was identified with 2 postoperative patients, and atrial fibrillation was observed with 1 postoperative patient as complications. Blood transfusion was performed with $71 \%$ of our patients $(n=10)$ due to an intraoperative and/or postoperative decline in the hemoglobin $(\mathrm{Hgb})$ level below $8 \mathrm{~g} / \mathrm{dL}$. Recurrence was detected in two patients, one locally and the other in the liver.

\section{DISCUSSION}

Although giant criteria for thoracic pathologies have not been fully defined, some studies describe the giant criteria as a lesion occupying more than half of the hemithorax (5). When literature and resources were investigated, such a definition for mediastinum could not be identified. The selection of the subjects of this study was based on the presence of the thoracic masses with radiological and pathological long axis of $15 \mathrm{~cm}$ or larger and pathological lesions that nearly occupy the whole mediastinum.

When Pubmed-NCBI screening was performed for the last 10 years typing 'giant tumors of the thorax', the pathologies obtained were as follows by frequency; malignant or benign chest wall tumors, solitary fibrous tumors, thymolipomas, thymic cysts, teratomas, desmoid tumors, myelofibroblastic tumors, thyroid and parathyroid tumors, schwannomas, and ganglioneuroblastoma. When compared with the pathological diagnosis of our patients, it is observed that it has parallels with the scan results. Moreover, benign or borderline tumors were found to be more common than malign tumors. It is known that malignant tumors occur to be mostly invasive and metastatic. Asymptomatic growth of giant masses can be explained by the poor ability of these types of masses to invade and metastasize. Benign tumors can generally be diagnosed with the symptoms that develop upon the increase in size and pressure on the surrounding tissues $(6,7)$. Only $4(29 \%)$ of our patients have a high-grade malignancy. These patients have limited invasion at the time of diagnosis and maintain the chance of resectability. 

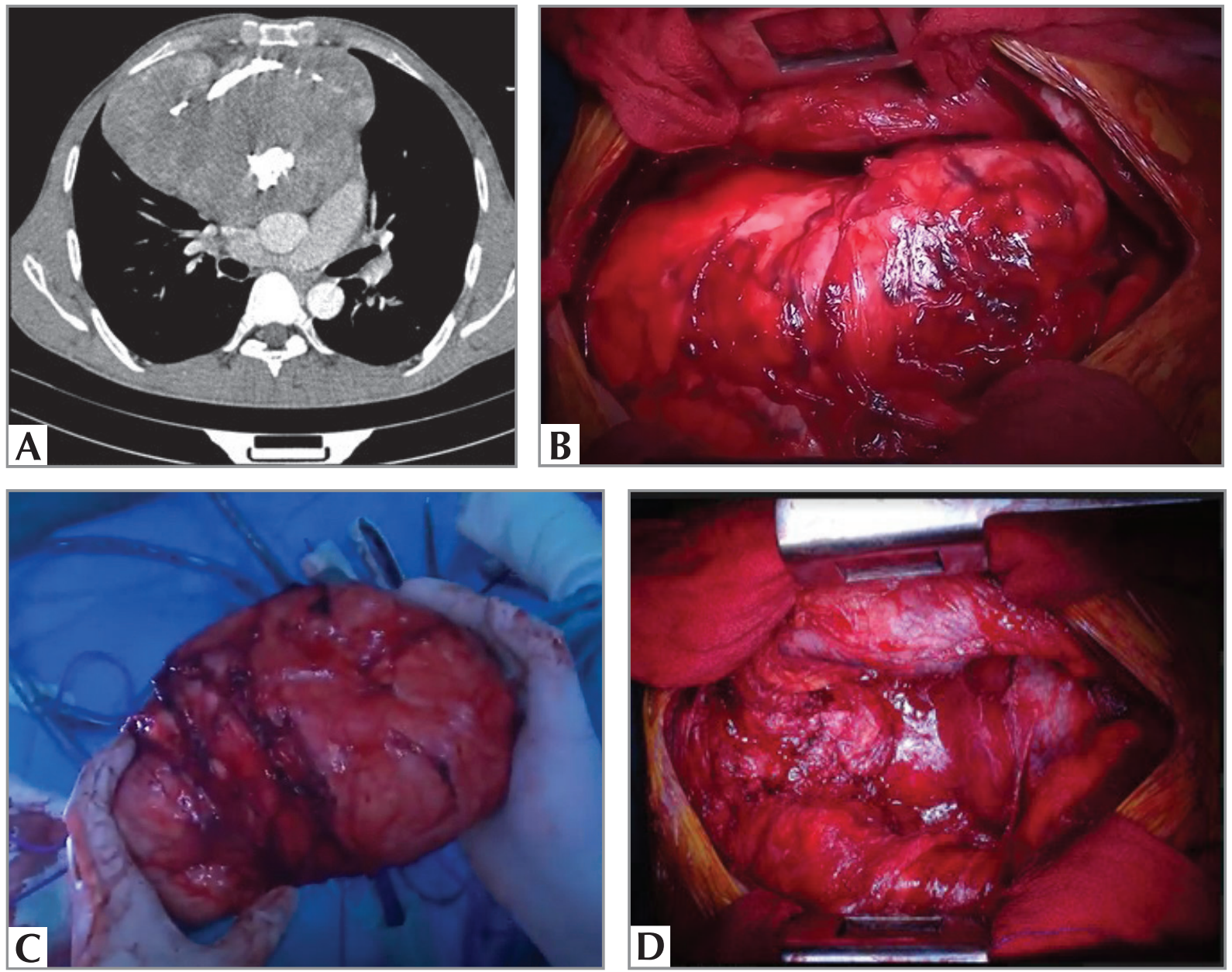

Figure 1. The story of patient number five resulting in spindle cell desmoid tumor pathology. A. Preoperative thorax CT, B. Intraoperative image, C. Image of the excised mass, D. Image of the surgical area after removal of the mass

The ability of slow-growing giant masses to show invasion indicates the degree of malignancy. However, the fact that tumors are encapsulated causes the tumors to be less invasive, even if they are very large in size and volume. Thymoma, schwannoma, benign solitary fibrous tumors, and Castleman disease fall into this category (8-10). This is not the case for the tumoral formations with non-capsular, malignant epithelial pathology. Such tumors include desmoid tumors, malignant solitary fibrous tumors, thymic carcinomas, malignant thyroid and paratroid tumors, and sarcomas. The spread of this type of malignancy is realized through deep level of invasion and the presence of distant metastases. It is usually inoperable at the diagnostic level (11-18). It is useful in the evaluation of mediastinal tumors in the surrounding area of the heart and in the detection of pericardial fluid and pericardial and myocardial invasion (19). The discussions below show the radiological evaluations that are used to determine the degree of invasion of intrathoracic giant masses into vital tissues. Also, echocardiography was used with our patients to determine the cardiac invasion. Echocardiography was performed with all of our patients with giant mediastinal masses. The results were confirmed by MRI. No myocardial invasion was detected with any of our patients. With two of our patients, no intraoperative pericardial invasion was observed.

\section{Radiology}

Intrathoracic tumors of the chest may be a diagnostic challenge both clinically and on imaging. The histopathological spectrum range from benign, to locally aggressive and malignancy. They have variable appearance on $\mathrm{CT}$. One of the discriminator features 
Table 2. Mass values excised after surgery

\begin{tabular}{|c|c|c|c|c|}
\hline Number & Surgery & $\begin{array}{l}\text { Pathologic Dimension } \\
18.4 \pm 3.6(15-23)\end{array}$ & Pathology & $\begin{array}{l}\text { Mass Weight } \\
844 \pm 473(350-2204)\end{array}$ \\
\hline 1 & MS & 23 & Thymolipoma & 1225 \\
\hline 2 & Th & 15 & Schwannoma & 650 \\
\hline 3 & MS & 15 & Teratoma & 550 \\
\hline 4 & MS & 20 & Mix Germ cell Tm & 350 \\
\hline 5 & MS & 21 & Spindle Cell Desmoid Tm & 850 \\
\hline 6 & Th & 16 & Leiomyosarcoma & 1255 \\
\hline 7 & Th & 15 & Spindle Cell Carcinoma & 949 \\
\hline 8 & Th & 21 & Solitary Fibrous Tm & 2204 \\
\hline 9 & Th & 15 & Solitary Fibrous Tm & 480 \\
\hline 10 & Th & 19 & Leiomyosarcoma & 700 \\
\hline 11 & Th & 15 & Solitary Fibrous Tn & 633 \\
\hline 12 & Th & 19 & GIST & 730 \\
\hline 13 & Th & 17 & Castleman & 450 \\
\hline 14 & MS & 23 & Thymomav thype $A B$ & 800 \\
\hline \multicolumn{5}{|c|}{$\begin{array}{l}\text { (Abbreviations: For surgical technic: Th: Thoracotomy, MS: Median sternotomy, for gastrointestinal tumor: GIST) Long axis was used as cm in Patho- } \\
\text { logic Dimension evaluation. } \\
\text { Gram parameter was used for the weight of the masses. }\end{array}$} \\
\hline
\end{tabular}

might be the localization of the tumor. Neurogenic tumors less commonly occur in the anterior and middle compartments, and they tend to be localized in posterior compartment. Nerve sheet tumors (schwannoma, neurofibroma) are one of the neurogenic tumor and usually well demarcated soft tissue masses which are usually hypodense on enhanced CT. They may contain calcification (10-50\%) or cystic component. In addition, tumors internal composition may help in diagnosis. The presence of fat attenuation on CT might facilitate the diagnosis and narrows the differential diagnosis as thymolipoma, lipoma, liposarcoma or teratoma. Teratomas are usually large (3-25 $\mathrm{cm}$ ) well-demarcated masses. Vast majority of these tumors are cystic in appearance and they have variable attenuation depending on the different content of different tissues. They might be uni or multiloculated. The fat-fluid level is highly specific for teratomas (20).

The enhancement pattern might be an another distinctive feature on CT. The intense enhancement helps narrow the differential diagnosis in intrathoracic masses which reflects the hypervascularity of the tumor and it is most common CT finding of a hyaline vascular variant of 'Castleman Disease' (21).

Intrathoracic desmoid tumors are very rare and are an aggressive tumor of the fibrous tissue. Like every intrathoracic tumors they have potential for local invasion. Desmoid tumors tend to have a high rate of recurrence even with total resection (22).

The giant tumors can show mass effect and they might compress cardiovascular and pulmonary (trachea) structures. They might invade adjacent lung parenchyma. Multilobulated masses with at least one acute angle between lobulations might be a predictive of lung invasion (23). The masses which invade mediastinal fat tissue may exhibit irregular borders. Direct endoluminal invasion of the vascular structure is rarely seen in giant intrathoracic masses. On the other hand, abutment of $>50 \%$ of a mediastinal vascular structure with loss of fat plane might be a predictor of vessel invasion. Diaphragmatic elevation, pleural effusion, mediastinal-retropleural lymph node enlargement might be other co-findings on CT (24).

\section{Surgical Technique}

The surgical intervention is determined based on the location of the pathological lesions. For large masses with anterior and superior mediastinum, median sternotomy is the preferred method whereas excision with posterolateral thoracotomy may be more appropriate for the tumors with posterior mediastinum and hemithorax. It is important to determine the shortest 
route to complete resection of the mass before deciding on the incisions. In addition, it will lead to fewer postoperative complications and cost minimal damage to the patient (25).

In order to prevent vascular injuries, it is important to determine the most suitable intervention for the exposure. The aorta, vena cava superior, pulmonary artery and veins, innominate artery and vein, carotis artery, subclavian artery and veins are the major vascular structures. Undesirable traumatic damage to these structures makes the operation difficult, increases the risk of intraoperative and postoperative mortality and morbidity, causes intraoperative and/or postoperative complications due to excessive transfusion, and causes the development of complications due to cardiac arrhythmia and insufficiency. It also prolongs the discharge when the complications secondary to postoperative pain occur due to the unnecessarily long cuts to create more exposure area upon bleeding (27-30).

Ten patients underwent median sternotomy while 5 patients underwent thoracotomy for the complete resection. None of our patients needed an additive incision. Although no adjacent organ invasion was observed with any of the masses, 2 patients diagnosed with solitary fibrous tumor had to have wedge resection due to the tight adhesion of the masses to the lingula of the left lung and the left lower lobe superior segment. Two patients developed simple wound infection and were treated with antibiotherapy. One patient developed atrial fibrillation on the second postoperative day and was followed up with medical cardioversion in normal sinus rhythm. Blood transfusion was performed with $71 \%$ of our patients $(n=10)$ due to an intraoperative and/or postoperative decline in the hemoglobin (Hgb) level below $8 \mathrm{~g} / \mathrm{dL}$.

For the excision of the masses, it is important to remove the encapsulated ones with its capsule while the lesions without the capsule are removed from the surrounding tissues based on R0 resection. For giant cystic tumors, the cyst can be drained allowing the mobilization to be more comfortable and the exposure to be at the desired level. However, this is not the case for solid lesions. For these lesions, lamination method has been defined as a method of easing the mobilization by shrinking the mass. By opening the capsule, the layers of solid tumors can be excised layer by layer through thermal cautery with lamination method. However, the procedure is stopped when the peduncle and the invasion are reached. The capsule can remain, which is not considered desirable for complete resection $(5,25)$.

Due to the narrow localization of these giant masses and poor exposure, VATS, which is a popular surgical method, is quite difficult to perform (25). None of our patients underwent the VATS.

\section{CONCLUSION}

In conclusion, these masses are pathologies in which complete resection can be performed and cure can be achieved, though their size can initially be intimidating.

Ethics Committee Approval: The ethical approval for this study was obtained from the Clinical Research Ethics Committee of Ankara University School of Medicine (Decision no: 1265 Date: 25.06.2020).

\section{CONFLICT of INTEREST}

There is no conflict of interest related to this study.

\section{AUTHORSHIP CONTRIBUTIONS}

Concept/Design: BMY,

Analysis/Interpretation: Fi, UY

Data Acquisition: AGÇ, YK, GK

Writting: BMY, AGÇ

Critical Revision: $\mathrm{CY}, \mathrm{SE}, \mathrm{MÖ}$

Final Approval: AKC

\section{REFERENCES}

1. Mani VR, Ofkwu G, Safavi A. Surgical resection of a giant primary liposarcoma of the anterior mediastinum. I Surg Case Rep 2015; 2015(9): rjv126.

2. Zaho H, Zhu D, Zhou Q. Complete resection of a giant mediastinal teratoma occupying the entire rigth hemithorax in a 14-year-old boy. BMC Surg 2014; 14: 56-8.

3. Sunam GS, Öncel M, Ceran S, Ödev K, Yıldıran H. Giant benign mediastinal masses extending into the pleural cavity. Surg J 2016; 2: e46-50.

4. Makdisi G, Roden AC, Shen RK. Successful resection of giant mediastinal lipofibroadenoma of the thymus by video-assisted thoracoscopic surgery. Ann Thorac Surg 2015; 100(2): 698-700.

5. Kallas E, Abrantes RD, Hueb AC. Tumor lamination in mediastinal giant tumors. Rev Col Bras Cir 2017; 44(6): 655-58

6. Taşdemiroğ/u E. Tümör-Metastaz Iliskisi; 154 Pediatrik Solid Malign Tümör Olgusunun Analizi Türk Nöroşirürji Dergisi 13: 8-11, 2003. 
7. Tarin D, Price JE, Kettlewell MG, Souter RG, Vass AC Crossley B. Mechanisms of human tumor metastases studied in patients with peritoneovenous shunts. Cancer Res 1984; 44(8): 3584-92.

8. Çakan A, Yuncu G, Olgaç G, Sevinç S, Aşkın M, Örs Kaya Ş ve ark. Primer mediasten tümör ve kistli 53 olgunun retrospektif değerlendirilmesi. Türk Gögüus Kalp Damar Cer Derg 2001; 9: 101-4.

9. Szolkowska M, Szczepulska-Wojcik E, Maksymiuk B, Burakowska B, Winiarski S, Gatarek J, et al. Primary mediastinal neoplasms: a report of 1005 cases from a single institution. J Thorac Dis 2019; 11(6): 2498-511.

10. Macchiarini P, Ostertag H. Uncommon primary mediastinal tumours. Lancet Oncol 2004: 5(2): 107-18.

11. Magdeleinat $P$, Alifano $M$, Petino A, Le Rochais JP, Dulmet $E$, Gaalateau F. Solitary fibrous tumor of pleura: clinical charateristic, surgical treatment and outcome. Eur J Cardiothorac Surg 2002; 21: 1087-93.

12. Veronesi G, Spaggiari L, Mazzarol G, De Pas M, Leo F, Solli P. Huge malignant localized fibrous tumor of the pleura. J Cardiovasc Surg 2000; 41: 781-4.

13. Valenzuela Q, Fernandez P, Escobar H. Giant desmoid tumor of the chest wall with intrathoracic growth. Arch Bronconeumol 2018; 54(10): 525.

14. Harish K. Recurrent large thoracic desmoid. Singapore Med J 2008: 49(11): e322.

15. Cardoso PF, da Silva LC, Bonamigo TP, Geyer G. Intrathoracic desmoid tumor with invasion of the great vessels. Eur I Cardiothorac Surg 2002; 22: 1017-9.

16. Ozawa M, Fukushima T, Noguchi T, Kobayashi T, Sekiguchi $N$, Koizumi T. Intra-oesophageal invasion of thymoma. Respirol Case Rep 2019;7(8): e00485.

17. Chen $X, X u H, N i Y$, Sun $K, L i W$. Complete excision of a giant thyroid goiter in posterior mediastinum. J Cardiothorac Surg 2013; 8: 207.

18. Carter BW, Marom EM, Detterbeck FC. Approaching the patient with an anterior mediastinal mass: a guide for clinicians. J Thorac Oncol 2014; 9 (9 Suppl 2): S102-S109.

19. Diagnosis of intathoracic masses by transesophageal color Doppler echocardiography. Chin Med J 1997; 110(9): 701-3.
20. Fulcher AS, Proto AV, Jolles H. Cystic teratoma of the mediastinum: demonstration of fat/fluid level. AJR Am J Roentgenol 1990; 154(2): 259-60.

21. Doo KW, Kim B. Castleman's disease presenting as a pleural tumor: a case report with CT findings. Radiol Case Rep 2017; 13: 18-20.

22. Dosios TJ, Angouras DC, Floros DG. Primary desmoid tumor of the posterior mediastinum. Ann Thorac Surg 1998; 66: 2098-9.

23. Green DB, Eliades S, Legasto AC, Askin G, Port IL, Gruden If. Multilobulated thymoma with an acute angle: a new predictor of lung invasion. Eur Radiol 2019; 29: 4555-62.

24. Marom EM, Rosado-de-Christenson ML, Bruzzi JF, Hara M, Sonett JR, Ketai L. Standard report terms for chest computed tomography reports of anterior mediastinal masses suspicious for thymoma. I Thorac Oncol 2011; 6: 171723.

25. Aydemir B, Çelik S, Okay T, Doğusoy I. Intrathoracic giant solitary fibrous tumor. Am J Case Rep 2013; 14: 91-3.

26. D'Andrilli A, Venuta F, Rendina EA. Surgical approaches for invasive tumors of the anterior mediastinum. Thorac Surg Clin 2010; 20: 265-84.

27. Vaporciyan AA, Rice D, Correa AM, Walsh G, Putnam JB, Swisher $S$, et al. Resection of advanced thoracic malignancies requiring cardiopulmonary bypass. Eur I Cardiothorac Surg 2002; 22: 47-52.

28. Gómez-Caro A, Martinez E, Rodríguez A, Sanchez D, Martorell J, Gimferrer IM, et al. Cryopreserved arterial allograft reconstruction after excision of thoracic malignancies. J Thorac Dis 2019; 11 (Suppl 13): S1653-S1661.

29. Tanaka Y, Hokka D, Ogawa H, Shimizu N, Inoue T, Tanaka $H$, et al. Surgery for malignant lesions of the chest which extensively involved the mediastinum, lung, and heart. Gen Thorac Cardiovasc Surg 2017; 65: 365-73.

30. Wang J, Yan J, Ren S, Guo Y, Gao Y, Zhou L. Giant neurogenic tumors of mediastinum: report of two cases and literature review. Chin I Cancer Res 2013; 25(2): 259-62. 